\title{
Koncepcja umowy administracyjnej na przykładzie umowy o dotację w świetle polskich i zagranicznych regulacji
}

\section{The Grant Agreement as an Example of the Concept of the Government's Contract - the analysis of Polish and Foreign Regulations}

Streszczenie. Choć umowy zawierane przez polskie organy administracji publicznej są przedmiotem obszernych badań naukowych zaprezentowanych w literaturze polskiej doktryny prawa administracyjnego, nie doczekały się swej ustawowej klasyfikacji i standaryzacji. Wzorcowe regulacje w tym zakresie zostały natomiast wprowadzone w innych krajach, np. w Niemczech i we Francji, już w ubiegłych wiekach (XIX i XX w.) i stosowanie tam instytucji tzw. umowy administracyjnej nie spotyka się z barierami analogicznymi do tych, które obserwowane są w Polsce. Artykuł przedstawia te bariery na przykładzie nierozstrzygniętego charakteru prawnego umowy dotacyjnej. Podjęta w nim zostanie próba odniesienia niemieckiej i francuskiej koncepcji umowy administracyjnej do umów zawieranych przez polską administrację, w tym w szczególności do umowy dotacyjnej. 
Słowa kluczowe: umowa administracyjna; umowa dotacyjna; dotacja publiczna.

\begin{abstract}
Contracts made by the Polish government were widely commented by Polish administrative law scholars. Nevertheless, these contracts have not been regulated and standardized by law as yet. Models of regulations in this area were, however, introduced in previous centuries (in XIX and in XX century) in other countries (e.g. Germany and France) and they have been practiced without any barriers since then. The opposite situation can be observed in Poland. This article present barriers which were identified in Poland. To this purpose a grant agreement serves as an exemplification of the agreement, which legal character is not specified by law. This contribution is accompanied by a comparison of German's and French concepts of government's agreement and Polish government's agreements, in particular to the grant agreement (the grant contract).
\end{abstract}

Keywords: a government's agreement; a grant agreement; a public subsidy.

\title{
1. Wprowadzenie
}

Obserwacja procesu wprowadzania umowy administracyjnej do polskiego systemu prawnego, który jak na razie nie został zakończony, skłania do podejmowania głębszych badań nad tą formą działania administracji. Badania te powinny przynieść odpowiedź na pytanie, dlaczego pomimo wieloletniej tradycji funkcjonowania umowy administracyjnej w innych krajach (nie tylko europejskich) próby prawnego uregulowania tej umowy w Polsce nie udają się. Jest to zaskakujące tym bardziej, że dynamicznemu rozwojowi i regulacji ustawowej uległy już w Polsce ugodowe i mediacyjne metody działania administracji, podczas gdy zawierane przez administrację umowy jak dotychczas nie doczekały się swej klasyfikacji i standaryzacji. W sferze umów zawieranych przez polskie organy administracji publicznej istnieje więc nadal stan niepewności i zamieszania prawnego, co w szczególnej mierze odnosi się do umów o zamówienia publiczne, umów z zakresu pomocy społecznej, a także coraz powszech- 
niej zawieranych (także na szczeblu władzy samorządowej) - umów o dotację (umów dotacyjnych) ${ }^{1}$.

Należy pozytywnie ocenić fakt wprowadzania do polskiego systemu prawnego niewładczych form działania administracji publicznej opartych na zasadach kooperacji, dyspozytywności i kontradyktoryjności. Proces ten nie jest jednak skoordynowany i nie następuje ewolucyjne. Przykładem mogą być właśnie umowy dotacyjne zawierane w latach 90. XX w. przez polskie organy wykonawcze jednostek samorządu terytorialnego (dalej: j.s.t.), kiedy nie miały one swych wyraźnych podstaw prawnych, a były zawierane głównie w celu zwiększenia bezpieczeństwa wydatkowania środków dotacyjnych na wskazany w ustawie cel publiczny. Do dnia dzisiejszego zresztą niektóre umowy dotacyjne zawierane przez organy wykonawcze j.s.t. (np. umowy o dotację na prace przy zabytkach) nie mają swych wyraźnych podstaw ustawowych, a możliwość ich zawierania dla swej legalności musi uzyskać podstawę prawną w akcie prawa miejscowego (w tzw. dotacyjnej uchwale trybowej). Pojawienie się umowy dotacyjnej w polskim prawie finansowym poprzez wprowadzenie jej regulacji po raz pierwszy do ustawy o finansach publicznych z $1998 \mathrm{r}$. (dalej: u.f.p. z 1998 r.), należy łączyć z dotacyjno-kontraktową metodą redystrybuowania przedakcesyjnych i strukturalnych środków Unii Europejskiej, co do których umowną formę przekazywania ustanawiał art. 30b tej ustawy. Uwzględniając fundamentalne zasady finansów publicznych (odmienne od zasad finansów prywatnych), wspomniana umowa o dotację była niejako zwiastunem nadchodzącej nowej ery w sektorze publicznym - ery, w której władcza i administracyjna metoda działania organów administracji (w tym organów samorządu terytorialnego) w sprawach finansowych będzie powoli zastępowana przez metodę umowną i cywilistyczną.

Kolejnym krokiem ku upowszechnieniu metody kontraktowej w działalności administracji było ustawowe uregulowanie w 2003 r. aktywności podmiotów tzw. trzeciego sektora (co do których umowną formę

$1 \quad$ W literaturze i orzecznictwie na określenie umowy przewidującej przekazanie dotacji ze środków publicznych stosowane są różne zwroty np.: umowa o dotację, umowa dotacji lub umowa o wykorzystanie dotacji. Zob. np. wyrok NSA z 11 stycznia 2011 r., II GSK 736/10, CBOSA. 
przekazywania im dotacji ustanawiały art. 71 i art. 118 u.f.p. z 1998 r. ${ }^{2}$ ). Wówczas również po raz pierwszy Minister Gospodarki, Pracy i Polityki Społecznej ustanowił rozporządzeniem ramowy wzór umowy o wykonanie zadania publicznego, który wywołał niespodziewaną dyskusję w sprawie dopuszczalności tak szerokiej ingerencji w sferę cywilistycznej samodzielności j.s.t. Następne rozporządzenia (z 2005 r., z 2010 r. i z 2016 r.) ustanawiające znowelizowany wzór powyższej umowy doprowadziły jednak do zaniku tej dyskusji i powszechnej akceptacji ramowego wzoru umowy jako narzędzia legislacyjnego ${ }^{3}$. Charakterystyczne jest jednak to, iż wszystkie wzory umów ustanowione powyższymi rozporządzeniami w postanowieniach końcowych formułują zasadę stosowania w zakresie nieuregulowanym w umowie przepisów ustawy o finansach publicznych i kodeksu cywilnego, nie odwołują się zaś do przepisów prawa administracyjnego, np. przepisów o umowie administracyjnej uregulowanych w k.p.a. ${ }^{4}$, gdyż jak dotychczas w polskim systemie prawnym przepisów takich nie ma, chociaż próba ich ustanowienia była podjęta w 2016 r.

Celem niniejszego artykułu jest przybliżenie i ocena wyżej wspomnianej próby wprowadzenia umowy administracyjnej do polskiego k.p.a. Dodatkowo zostanie w nim dokonana analiza adekwatności (możliwości zastosowania) proponowanych wówczas przepisów o umowie administracyjnej do umowy dotacyjnej (umowy o dotację). Odwołując się do regulacji funkcjonujących w tym zakresie w Niemczech i we Francji, a także do

2 Kolejna u.f.p. z 2005 r. regulowała umowę dotacyjną w art. 130 (w odniesieniu do dotacji celowych udzielanych z budżetu państwa) oraz w art. 189a (mającym charakter odsyłający - w odniesieniu do dotacji udzielanych z budżetu j.s.t.). Obecnie umowy dotacyjne są uregulowane $\mathrm{w}$ art. $150 \mathrm{i}$ art. 250 ustawy z 27 sierpnia 2009 r. o finansach publicznych (tekst jedn. Dz.U. z 2017 r., poz. 2077).

3 Nadal jednak istotne wątpliwości wzbudzają wzory umów ustanawiane przez organy stanowiące j.s.t. w tzw. dotacyjnych uchwałach trybowych, wydawanych np. na podstawie art. 27 ust. 2 ustawy o sporcie. Niektóre kolegia RIO unieważniają wzory takich umów załączane do uchwał, gdyż ich zdaniem „zawarcie umowy i w konsekwencji kształtowanie jej treści należy do kompetencji organu wykonawczego gminy jako organu zobowiązanego do wykonywania budżetu gminy i uchwał rady”. Zob. uchwała nr 43/193/10 Kolegium RIO w Łodzi z 15 grudnia 2010 r., OwSS 2011/1, s. 101 oraz szerzej: A. Ostrowska, Dotowanie sportu przez jednostki samorzqdu terytorialnego, „Finanse Komunalne” 2013, nr 12, s. 17.

4 Ustawa z dnia 14 czerwca 1960 r. Kodeks postępowania administracyjnego (tekst jedn. Dz.U. z 2017 r., poz. 1256), dalej: k.p.a. 
innych umów quasi-administracyjnych zawieranych przez polskie organy administracji publicznej, w artykule podjęta zostanie próba odpowiedzi na pytanie, czy umowa dotacyjna może być uznana za umowę administracyjną, a jeśli tak, to jaki wzorzec umowy administracyjnej powinien mieć do niej zastosowanie.

\section{Umowy administracyjne w Niemczech i we Francji}

Badania poświęcone kwestii dopuszczalności stosowania umów w prawie publicznym mają w Niemczech ponad stuletnią tradycję i obejmują obszerną literaturę nauki prawa administracyjnego. Początkowo umowy administracyjne były odrzucane przez zdecydowaną większość przedstawicieli tej nauki. Istotę rozważań koncentrowano wokół konstytucyjnej zasady praworządności, a więc w jakim stopniu wprowadzenie elementów kooperacji do postępowania administracyjnego (wprowadzenie umowy administracyjnej) prowadzi do zmiany koncepcji związania administracji prawem. Po latach dyskusji nad umową administracyjną toczonej w doktrynie umowę tę w 1977 r. uregulowano w federalnej ustawie o postępowaniu administracyjnym. Charakteryzując genezę wprowadzenia umowy administracyjnej do niemieckiego systemu prawa, Z. Cieślik podkreśla, że „umowa administracyjna jest instytucją charakterystyczną dla szczególnej formy państwa prawnego, tj. socjalnego państwa prawa (...). Włączeniu jej do systemu prawa administracyjnego towarzyszy zawsze osłabienie rygorów zasady związania administracji prawem. Proces przekształcania się państwa liberalnego w państwo socjalne jest równoległy do procesów reinterpretacji założeń praworządności ustroju oraz do rozszerzania się zakresu aktywności władzy publicznej. Wprowadzenie umowy administracyjnej do porządku prawnego jest formą reakcji na głębokie przemiany w pojęciu roli władzy publicznej. Funkcja ochronna instytucji oraz zawarty w jej konstrukcji element demokratyzacji postępowania administracyjnego są wtórne wobec prawdziwego zadania, dla jakiego została 
ona powołana - sprostania nowej sytuacji, w jakiej znalazło się państwo pod koniec XX wieku” ${ }^{\text {. }}$.

W nauce prawa niemieckiego zastanawiano się, w jakim stopniu wprowadzenie elementów kooperacji do postępowania administracyjnego prowadzić będzie do zmiany koncepcji związania administracji prawem. Koncepcje administracji świadczącej oraz socjalnego państwa prawa wymusiły „poluzowanie” rygorystycznej zasady legalizmu (charakterystycznej państwu liberalnemu), które następnie dało ustrojowe podstawy do prawnego uregulowania umowy administracyjnej.

Z analizy przepisów federalnej ustawy z dnia 25 maja 1976 r. o postępowaniu administracyjnym regulujących umowę administracyjną (§ 54-61 VwVfG) wyłania się koncepcja umowy administracyjnej będącej jedną z form załatwiania sprawy zawisłej w postępowaniu administracyjnym. W odniesieniu do niemieckiej umowy administracyjnej wymienić więc można następujące jej cechy ${ }^{6}$ :

- zgodnie z ustawową definicją umową administracyjną jest umowa, która uzasadnia, zmienia lub znosi stosunek prawny w dziedzinie prawa publicznego;

- umowy administracyjne mają charakter subsydiarny w stosunku do jednostronnych aktów administracyjnych; mogą być stosowane wówczas, gdy nie zostały zakazane przez ustawodawcę generalnie bądź w konkretnym przypadku; organ administracyjny ma uznanie, kiedy stosować formę umowy, a kiedy - akt administracyjny; uznanie to jest ograniczone jedynie przez wyraźny zakaz stosowania umowy lub nakaz wydania aktu administracyjnego;

- generalne wyłączenie (zakaz stosowania) umowy administracyjnej dotyczy m.in. podatków i opłat lokalnych, przy określaniu których wymagana jest forma decyzji; zakaz ten nie obejmuje jednak takich kwestii jak np. ustalenie sposobu zapłaty podatku lub opłaty;

Z. Cieślik, Umowa administracyjna w państwie prawa, Kraków 2004, s. 12.

Por. E. Stefańska, Umowy zawierane w sferze administracji publicznej - wybrane zagadnienia, [w:] J. Boć, L. Dziewięcka-Bokun (red.), Umowy w administracji, Wrocław 2008, s. 145-160; A. Śledzińska, Umowy administracyjne w prawie i praktyce innych krajów, [w:] J. Boć, L. Dziewięcka-Bokun (red.), Umowy..., s. 179-192. 
- pojęcie umowy administracyjnej nie obejmuje wszelkich sytuacji umownych, lecz zasadniczo ograniczone jest do umów zawieranych w toku postępowania administracyjnego, zastępujących akt administracyjny;

- $\quad$ w odniesieniu do sporów wynikających z umów administracyjnych przewidziano administracyjnoprawną drogę ich rozstrzygania zarówno w przypadku wynikających z umowy roszczeń o spełnienie świadczenia, jak i w przypadku wynikających z umowy roszczeń odszkodowawczych;

- $\quad$ umowy administracyjne dzielą się na: umowy subordynujące (subordinationsrechtlicher Vertrag), zawierane między stronami znajdującymi się wobec siebie w stosunku podległości (czyli między podmiotem administrującym a podmiotem administrowanym) ${ }^{7}$ oraz umowy koordynujące (koordinationsrechtlicher Vertrag), zawierane między podmiotami równorzędnymi, w szczególności między podmiotami administrującymi (organami administracji), regulujące stosunki publicznoprawne dotyczące m.in. współdziałania; niemiecka ustawa o postępowaniu administracyjnym większość swych przepisów odnosi przede wszystkim do umów subordynujących;

- $\quad$ szczególnym rodzajem umowy administracyjnej jest ugoda, która umożliwia organowi administracji osiągnięcie kompromisu w sprawach, w których względy ekonomii procesowej przemawiają za polubownym załatwieniem sprawy; ugodę uznaje się za typ umowy administracyjnej najluźniej związanej z zasadą państwa prawa.

Istotą niemieckiej umowy administracyjnej jest jej subsydiarność (alternatywność wobec jednostronnego aktu administracyjnego) oraz fakt, iż jest ona formą zakończenia postępowania administracyjnego ustanawiającą inne niż przewidziane prawem materialnym publicznoprawne obo-

7 Przykładem umowy subordynującej są tzw. umowy wymiany, które są zawierane przez organ administracji (zobowiązujący się do wydania określonego aktu) z obywatelem (zobowiązującym się do odpowiedniego świadczenia o charakterze majątkowym). Spory powstałe na tle tego typu umów rozstrzygane są przez organy nadzoru i sądy administracyjne. Zob. D.R. Kijowski, W sprawie charakteru prawnego umów zawieranych przez organy administracji, „Państwo i Prawo” 1987, nr 6, s. 83. 
wiązki i uprawnienia stron umowy (organu administrującego i obywatela). Wśród typowych umów administracyjnych zawieranych w niemieckiej praktyce administracji publicznej można wymienić: porozumienia w postępowaniu wywłaszczającym, umowy zamiany zawierane w procedurze wydawania pozwolenia na budowę, umowy zamiany zawierane w zakresie gospodarowania nieruchomościami, a nawet $\mathrm{w}$ zakresie planowania przestrzennego ${ }^{8}$.

We Francji doktrynalne i normatywne podstawy umowy administracyjnej również posiadają swą długoletnią historię. W początkowym okresie za umowy administracyjne uznawano tylko umowę dostawy i umowę robót publicznych, jednakże w dalszych latach (w XIX w.) objęto nią wszystkie umowy związane ze służbą publiczną - mające na celu realizację zadań związanych ze służbą publiczną administracji (działaniem w interesie publicznym). Przyjmuje się, że są to przede wszystkim kontrakty zawierane przez państwo i inne osoby prawa publicznego z podmiotami prywatnymi w celu uzyskania dóbr i usług użyteczności publicznej (wszystkie rodzaje zakupów „marches”). Umowy administracyjne we Francji nie mają swego odrębnego uregulowania ustawowego (kodeksowego $)^{9}$, lecz zostały ukształtowane jako takie przez orzecznictwo sądów administracyjnych i naukę prawa administracyjnego. Uzyskują one status umowy administracyjnej poprzez ich określenie jako takie w poszczególnych ustawach materialnych (np. w ustawie o zamówieniach publicznych) albo też uzyskują ten status poprzez zawarcie w jej treści tzw. klauzul nadmierności, z których wynika, że administracja zamierza stosować wobec strony umowy uprawnienia władcze (np. w zakresie uprawnień kontrolnych). Umowami administracyjnymi są także umowy, które podporządkowane są specjalnemu reżimowi prawa, przyznającemu administra-

\footnotetext{
Zob. szerzej: Z. Cieślik, Umowa..., s. 39-40.

Obok Niemiec, ustawowe regulacje umowy administracyjnej występują w Estonii, Finlandii, Grecji, Gruzji i Hiszpanii. W większości z tych krajów umowa ta pojawiła się pod wpływem tendencji zastępowania władczych form działania administracji formami niewładczymi (dwustronnymi i ugodowymi), a także wynikała z ogólnoeuropejskich przemian w kulturze sprawowania władzy publicznej i z realizacji koncepcji społeczeństwa obywatelskiego. Zob. A. Doliwa, Osobowość prawna jednostek samorzq̨du terytorialnego, Warszawa 2012, s. 294.
} 
cji szczególne uprawnienia regulacyjne lub kontrolne. Z nauki i orzecznictwa francuskich sądów administracyjnych wyłaniają się następujące cechy umowy administracyjnej ${ }^{10}$ :

- $\quad$ umowa administracyjna musi być zawierana bezpośrednio w powiązaniu ze służbą publiczną, czyli bezpośrednio w celu realizacji przez administrację zadań publicznych;

- $\quad$ w przypadku, gdy umowa zawierana jest wyłącznie przez podmioty prawa publicznego, obowiązuje domniemanie, że kontrakt ma charakter administracyjny;

- umowa zawarta między podmiotem publicznym a podmiotem prywatnym staje się umową administracyjną pod warunkiem zawarcia w niej tzw. klauzul nadmierności, a także pod warunkiem poddania jej reżimowi prawa administracyjnego;

- $\quad$ umowy administracyjne są wyłączone spod reżimu prawa cywilnego, zaś rozstrzyganie sporów powstałych w trakcie ich realizacji należy do właściwości sądów administracyjnych;

- $\quad$ pozycja strony reprezentującej administrację publiczną jest silniejsza niż strony prywatnoprawnej, a swobody kontraktowe są istotnie ograniczone (np. poprzez jednostronne wyznaczanie przez administrację ogólnych i szczególnych wymagań co do treści umowy).

Podsumowując charakter francuskiej umowy administracyjnej, należy wskazać, iż uprawnienia władcze administracji publicznej jako strony tej umowy są wyjątkowo szerokie w porównaniu z regulacjami w innych państwach, w tym w szczególności w porównaniu z rozwiązaniami przyjętymi w Polsce. W 2002 r. przekazano tam nawet do właściwości sądów administracyjnych także umowy, które tradycyjnie należały do umów prywatnoprawnych (np. umowy ubezpieczenia). To „sztuczne” wydzielenie umów administracyjnych od umów cywilnych zawieranych przez administrację spotyka się jednak z głosami krytyki we francuskiej nauce prawa administracyjnego.

10 Zob. szerzej: M. Maciołek, Kryteria kwalifikacyjne kontraktu administracyjnego we francuskiej nauce prawa administracyjnego, „Studia Iuridica” 1996, t. 32, s. 173; J. Zimmermann, Prawo administracyjne, Warszawa 2016, s. 435-437; E. Stefańska, Umowy..., s. 153. 


\section{Próba wprowadzenia umowy administracyjnej do polskiego k.p.a.}

W Polsce umowa administracyjna (publicznoprawna) nadal ma charakter jedynie koncepcji doktrynalnej, jakkolwiek w przeszłości podejmowane były inicjatywy legislacyjne w zakresie ustawowego uregulowania tej umowy, np. złożony 29 grudnia 2010 r. w Sejmie VI kadencji projekt ustawy - Przepisy ogólne prawa administracyjnego ${ }^{11}$ czy też projekt nowelizacji k.p.a. z 2016 r. Ta ostatnia inicjatywa zasługuje na szersze rozpatrzenie właśnie w aspekcie możliwości jej zastosowania do umowy dotacyjnej.

W Ministerstwie Rozwoju RP przygotowano w 2016 r. projekt nowelizacji k.p.a., który zawierał propozycje nowych przepisów o umowie administracyjnej (art. 113a-113f). Przepisy te nie formułowały jednak definicji tej umowy, a ponadto została ona określona jako forma załatwienia sprawy administracyjnej ${ }^{12}$, kończącej wszczęte wcześniej postępowanie administracyjne. Proponowany przepis art. 113a stanowił, że „załatwienie sprawy może nastąpić przez zawarcie umowy administracyjnej pomiędzy organem administracji publicznej prowadzącym postępowanie a stroną tego postępowania, o ile charakter sprawy na to pozwala”. Jak wskazuje się w uzasadnieniu projektu wspomnianej ustawy nowelizującej k.p.a., „umowa administracyjna będzie alternatywnym, wobec decyzji administracyjnej, sposobem załatwienia sprawy. Z chwilą jej zawarcia, umowa będzie wywoływała skutki decyzji”"13. Z pewnością więc projek-

11 Druk nr 3942, Sejm RP VI kadencji, www.sejm.gov.pl, (dostęp: 3.07 .2018 r.).

12 Należy w tym miejscu wspomnieć, iż zarówno w doktrynie prawa administracyjnego, jak i w orzecznictwie nie ma zgodności co do definicji „sprawy administracyjnej”. Większość opowiada się jednak za szeroką interpretacją tego pojęcia, tym samym też szeroko interpretując akty organów j.s.t. podejmowane w sprawach z zakresu administracji publicznej, które zostały poddane kontroli sądowoadministracyjnej. Zob. postanowienia SN: z dnia 24 września 1997 r., III RN 41/97, z dnia 3 września 1998 r., III RN 52/98, Baza orzeczeń, www.sn.pl oraz uchwałę TK z 27 września 1994 r., W 10/93, www.otkzu.trybunal.gov.pl, w której TK szeroko definiuje działalność komunalną jako „wszelką działalność gmin”.

13 Uzasadnienie do projektu ustawy o zmianie ustawy - Kodeks postępowania administracyjnego oraz niektórych innych ustaw, druk nr UD33 z dnia 4 lipca 2016 r., s. 14, http://legislacja.rcl.gov.pl/projekt/12287313, (dostęp: 3.07.2018 r.). 
towane regulacje polskiego k.p.a. o umowie administracyjnej wpisywały się w niemiecką koncepcję tej umowy, przy czym w polskich regulacjach nie zdecydowano się na wprowadzenie podziału na umowy subordynujące i umowy koordynujące, a także nie przewidziano administracyjnej drogi rozstrzygania sporów powstałych w trakcie jej realizacji. Uwzględniając istniejące już w polskim k.p.a. przepisy o ugodzie administracyjnej (art. 114-122), a także proponowane w powyższym projekcie również nowe przepisy o mediacji (art. 96a-96l, które są już przepisami obowiązującymi) można by podjąć dyskusję, zadając pytanie: czy kolejna, nowa forma negocjacyjnego załatwiania spraw administracyjnych (w tym spraw dotyczących zwrotu dotacji) jest potrzebna?

Odpowiedź na powyższe pytanie powinna być pozytywna, jednakże tylko w przypadku rozszerzenia projektowanych przepisów o umowie administracyjnej (analogicznie do przepisów niemieckiej ustawy o postępowaniu administracyjnym), a także ze względu na niezwykle ograniczony zakres podmiotowy zastosowania polskiej ugody administracyjnej. Pomimo bowiem tego, że np. administracyjna sprawa zwrotu dotacji jest zawisła przed organem administracji i dotyczy toczącego się postępowania administracyjnego, nie może być ona załatwiona w wyniku zawarcia ugody administracyjnej (art. 114-122 k.p.a.), gdyż w świetle polskiego k.p.a. niedopuszczalne jest zawarcie ugody między organem administracji publicznej a podmiotem mającym interes prawny w załatwieniu sprawy administracyjnej. W odniesieniu do administracyjnego trybu dochodzenia zwrotu dotacji zastosowanie przepisów k.p.a. o ugodzie administracyjnej (art. 114-122 k.p.a.) oraz wprowadzonych z dniem 1 czerwca 2017 r. przepisów k.p.a. o mediacji administracyjnej (art. 96a-96n k.p.a.) wywołuje wątpliwości właśnie z powodu przyjętej przez polskiego ustawodawcę ograniczonego zakresu podmiotowego samej ugody administracyjnej. Ostatnia nowelizacja k.p.a. nie usunęła bowiem powyższej cechy ugody administracyjnej, pozostawiając ją w dotychczasowym układzie wertykalnym. „Polska ugoda administracyjna nie jest dosłownie działaniem dwustronnym rozumianym jako działalnie wspólne organu administracji publicznej i podmiotu zewnętrznego, ale działaniem podejmowanym przez dwa podmioty zewnętrzne wobec administracji publicznej. Ugoda taka 
przypomina ugodę w postępowaniu sądowym, jakkolwiek jej ważną cechą administracyjnoprawną jest obowiązek zatwierdzenia. (...) Ugoda jest zawierana tylko pomiędzy stronami postępowania administracyjnego przed organem prowadzącym to postępowanie. Wyklucza to możliwość jej zawarcia między organem a stroną"14.

Zaproponowana w powyższym projekcie nowelizacji k.p.a. wąska formuła umowy administracyjnej - jako aktu kończącego wszczęte już postępowanie administracyjne - nie rozwiązywała kwestii charakteru prawnego licznych umów zawieranych przez polskie organy administracji, w tym przez organy wykonawcze j.s.t. z podmiotami publicznymi i prywatnymi, przewidujących finansowe wsparcie/zapłatę/dotację ze środków publicznych, a które przecież w większości przypadków nie są zawierane w efekcie formalnie wszczętego wcześniej postępowania administracyjnego. Wprawdzie istnieją orzeczenia NSA uznające, iż czynności podejmowane przez organ administracji przed zawarciem umowy o wsparcie finansowe ze środków publicznych (np. czynności konkursowe) są czynnościami administracyjnymi ${ }^{15}$, jednakże żadna ustawa przewidująca udzielanie dotacji (wsparcia, dofinansowania itd.) ze środków publicznych (w tym z budżetu j.s.t.) tej kwestii nie reguluje wprost. W takim stanie ustawodawstwa dotacyjnego nie można więc przyjąć, że wprowadzenie nowych przepisów k.p.a. o umowie administracyjnej w wersji zaproponowanej we wspomnianym projekcie rozwiąże problem mieszanego charakteru prawnego umów dotacyjnych, które, kierując się klasyfikacjami doktrynalnymi, należałoby zaliczyć do grupy tzw. umów administracyjnych specjalnych.

Podjęta w 2016 r. próba wprowadzenia tzw. umowy administracyjnej do polskiego k.p.a. wpisywała tę umowę w klasyczny obszar administrowana (urzędowania), co nie rozwiązywało wątpliwości panujących wokół charakteru prawnego umowy dotacyjnej lub wielu innych umów o podobnym charakterze zawieranych przez organy administracji publicznej. Zachodzącym w Polsce stosunkom dotacyjnym, w szczególności tym,

\footnotetext{
J. Zimmermann, Prawo..., s. 398.

Np. wyrok NSA z dnia 7 września 2005 r., II GSK 116/05, CBOSA.
} 
w których zawierana jest umowa dotacyjna, doktryna i orzecznictwo cywilne i administracyjne generalnie nadaje więc charakter cywilnoprawny.

Dostrzegając wyżej wymienione mankamenty projektowanych przepisów k.p.a. o umowie administracyjnej, które nie były jednak zgłaszane w trakcie procedury konsultacyjnej projektu, Rada Ministrów na posiedzeniu 6 grudnia 2016 r. postanowiła złożyć Marszałkowi Sejmu powyższy projekt nowelizacji k.p.a. z autopoprawką wyłączającą z projektu propozycje przepisów dotyczących umowy administracyjnej. Projekt ustawy zmieniającej kodeks (już bez przepisów o umowie administracyjnej) został przyjęty 7 kwietnia 2017 r. ${ }^{16}$

\section{Administracyjny czy cywilny charakter umowy dotacyjnej?}

W nawiązaniu do opisanej wyżej nowelizacji k.p.a. z 2016 r. należy wskazać, iż nawet gdyby utrzymano w powyższym projekcie proponowane przepisy o umowie administracyjnej, a następnie je uchwalono, nie rozwiązałoby to problemu braku systematyzacji umów zawieranych przez polskie organy administracji publicznej. Umowy administracyjne specjalne takie jak: umowa w sprawie zamówienia publicznego, umowa o wsparcie/powierzenie realizacji zadania publicznego organizacji pozarządowej, umowa o dofinansowanie prac przy zabytku, umowa o finansowanie zadań $\mathrm{z}$ zakresu ochrony środowiska oraz inne umowy/porozumienia przewidujące udzielenie dotacji ze środków publicznych podmiotowi zewnętrznemu (spoza sektora finansów publicznych) lub wewnętrznemu (należącemu do tego sektora) - nadal posiadałyby niejasny i mieszany (cywilno-administracyjny) charakter prawny oraz nadal w sytuacjach spornych poddane byłyby albo sądownictwu cywilnemu (w przypadku złożenia pozwu cywilnego przez beneficjenta dotacji) albo sądownictwu administracyjnemu (w przypadku wydania przez organ dotujący decyzji o zwrocie dotacji).

16 Ustawa z dnia 7 kwietnia 2017 r. o zmianie ustawy - Kodeks postępowania administracyjnego oraz niektórych innych ustaw (Dz.U. poz. 935). 
Niejednokrotnie na cywilny charakter powyższych umów wskazują same przepisy ustaw, choć najczęściej czynią to w sposób pośredni: albo w formie przekazania sądom powszechnym rozstrzyganie sporów zaistniałych między ich stronami, albo w formie zawartego w umowie odesłania (kompletacji) do k.c. w kwestiach nieuregulowanych w umowie ${ }^{17}$. Same poddanie tych umów kognicji sądu cywilnego lub umieszczenie w ich treści odesłania do k.c. nie czyni jednak z nich „czysto” cywilistycznych i prywatnych kontraktów, gdyż w rzeczywistości przewaga ich publiczno-administracyjnych cech nad cechami prywatno-cywilistycznymi jest znaczna. Jak wskazuje W. Gonet, odesłanie do k.c. czynione w umowach zawieranych przez organy administracji samorządowej (stosowanie k.c. do tych umów) jest naturalne, gdyż „kodeks cywilny oraz inne akty prawne nie zawierają przepisów szczególnych, które wyłączałyby stosowanie wobec j.s.t. kodeksu cywilnego, a w szczególności art. 3531”18.

Przepis art. $353^{1}$ k.c. ustanawiający zasadę swobody umów (układania przez strony umowy stosunku prawnego według swego uznania) wyznacza jednak trzy źródła ograniczeń tej swobody: przepisy ustaw, zasady współżycia społecznego oraz właściwość (natura) stosunku. W przypadku umów dotacyjnych zawieranych przez organy administracji publicznej ograniczenia swobody kontraktowania są liczne i wynikają zarówno z przepisów ustaw, jak i z właściwości (natury) stosunku prawnego, którego jedną ze stron lub obie strony są podmiotami sektora finansów publicznych i która przewiduje publiczno-prawną formę finansowania przedmiotu umowy (dotację). Ograniczenia swobody umów w zakresie

17 Przykładowo w sprawie umów o udzielenie przez j.s.t. pomocy finansowej innej j.s.t. art. 220 ust. 3 u.f.p. wprost stwierdza, iż ,spory w zakresie zwrotu dotacji rozstrzygają sądy powszechne”. Z kolei ustawa o działalności pożytku publicznego do umów zawieranych na podstawie tej ustawy (np. umowy o wykonanie inicjatywy lokalnej) w zakresie nieuregulowanym w ustawie wprost nakazuje stosować k.c. (art. 19h). W przypadku zaś umów o wsparcie/powierzenie realizacji zadania publicznego organizacji pozarządowej odesłanie do k.c. umieszczono w $\S 18$ pkt 2 wzoru umowy ustanowionym w rozporządzeniu MRPiPS, jednak w $\S 18$ pkt 1 wzoru umowy (a więc przed odesłaniem do k.c.) umieszczono kompletację do u.f.p., ustawy o rachunkowości, Prawa zamówień publicznych i ustawy o odpowiedzialności za naruszenie dyscypliny finansów publicznych.

18 W. Gonet, Zakres swobody zawierania umów przez jednostki samorzq̨du terytorialnego, Warszawa 2011, s. 58-62. 
umów dotacyjnych występują właściwie we wszystkich swobodach: począwszy od swobody wyboru kontrahenta (poprzez ustawowe określenie podmiotów mających prawo ubiegania się o dotację), poprzez swobodę kształtowania treści umowy (przez ustawowe lub miejscowe określenie obligatoryjnych elementów umowy i zasad dokonywania w niej zmian), a skończywszy na swobodzie sposobu kontraktowania (przez ustawowe lub miejscowe określenie trybu udzielania dotacji). To właśnie wyżej wymienione ograniczenia oraz szczególna natura prawna umowy dotacyjnej nie pozwalają traktować jej jako „czysty” kontrakt cywilno-prawny, lecz wskazują na jej charakter specjalny - charakter publicznoprawny.

Doktryna prawa administracyjnego, gospodarczego czy cywilnego opowiada się jednak w sposób jednoznaczny i zdecydowany za cywilnym charakterem umów dotacyjnych, co poniekąd wynika właśnie z obowiązujących niejednoznacznych przepisów prawa w ogóle nieregulujących tej kwestii. Ponadto za cywilnym charakterem wszelkich dwustronnych działań administracji opowiada się również większość orzecznictwa SN, NSA i WSA zapadającego w ostatnich latach. W orzecznictwie tym spotykany jest nawet podgląd, iż jeżeli podstawą udzielenia wsparcia finansowego ze środków publicznych jest umowa cywilnoprawna, taki też charakter mają czynności związane z jej zawarciem ${ }^{19}$. Nie są to zatem, zgodnie z tym orzecznictwem, sprawy podlegające kognicji sądów administracyjnych, co jednak nie pozbawia zainteresowanych skutecznej ochrony sądowej, ponieważ ewentualne roszczenia będą mogły być dochodzone w postępowaniu cywilnym przed sądem powszechnym. Istnieje jednak odmienne orzeczenie NSA w tej sprawie ${ }^{20}$, które wobec powszechnego poglądu o cywilnym charakterze umowy o dotację (i innych umów o wsparcie ze środków publicznych) należy uznać za precedensowy. W sprawie tej NSA

19 Por. np. postanowienie NSA z dnia 19 marca 2003 r., III SA 223/03, wyrok NSA z dnia 24 maja 2005 r., II GSK 70/05, uchwała NSA z 29 marca 2006 r., II GPS 1/06. W jednym z wyroków NSA wyraźnie wyłączył możliwość stosowania przepisów k.p.a. do postępowania konkursowego prowadzonego na podstawie art. 11-19 ustawy z 24 kwietnia 2003 r. o działalności pożytku publicznego i o wolontariacie (Dz.U. z 2016 r. poz. 1817 ze zm.), gdyż postępowanie to nie odpowiada żadnemu z postępowań wymienionych w art. 1 i art. 2 k.p.a. Zob.: wyrok NSA z 11 stycznia 2011 r., II GSK 736/10.

20 Wyrok NSA z 7 września 2005 r., II GSK 116/05. 
słusznie stwierdził, że kierowana do wnioskodawcy na podstawie art. 13a ust. 1 ustawy o finansowym wspieraniu inwestycji ${ }^{21}$ „informacja” o odmowie udzielenia wsparcia finansowego nowej inwestycji ma charakter decyzji administracyjnej. Zdaniem NSA „odmowa udzielenia takiego wsparcia nie ma charakteru oświadczenia cywilnoprawnego, gdyż organ nie występuje na tym etapie postępowania jako równoprawna strona stosunku cywilnoprawnego, lecz jako organ władczy wykonujący zadania publicznoprawne w ramach przyznanych mu kompetencji ustawowych. Należy podkreślić z całą mocą, że szczegółowa procedura udzielenia takiego wsparcia przewidziana w ustawie i przepisach wykonawczych upewnia, że mamy do czynienia z klasycznym postępowaniem administracyjnym, które powinno zakończyć się rozstrzygnięciem administracyjnym”.

Brak jednoznacznego określenia przez ustawodawcę charakteru prawnego umów przewidujących udzielanie dotacji ze środków publicznych przekłada się także na spór co do właściwości sądowej w sprawach dotyczących tych umów. Choć większość orzecznictwa SN i NSA, a także doktryny prawa administracyjnego, przychyla się do stricte cywilistycznego charakteru tych umów ${ }^{22}$ i tym samym właściwości sądów powszechnych w sprawach dotyczących ich wykonywania, to założenie o prawidłowości tego stanowiska trudno jest pogodzić z przyjętym administracyjnym trybem dochodzenia zwrotów dotacji mających przecież zastosowanie także do dotacji celowych przekazywanych umownie. W sferze dotacji udzielanych z budżetów publicznych w Polsce zaistniało rozdwojenie

21 Ustawa z dnia 20 marca 2002 r. o finansowym wspieraniu inwestycji (Dz.U. Nr 41, poz. 363), która została uchylona i zastąpiona ustawą z dnia 6 grudnia 2006 r. o zasadach prowadzenia polityki rozwoju (Dz.U. z 2016 r., poz. 383). W nowej ustawie utrzymano pisemne informowanie wnioskodawcy o wynikach oceny jego projektu, lecz jednocześnie wprowadzono instrument odwoławczy od takiej „informacji” w postaci protestu wnoszonego do właściwej instytucji zarządzającej (art. 30a i 30b). Protest jest rozpatrywany również $\mathrm{w}$ formie pisemnej informacji, od której ustawa przewidziała możliwość wniesienia skargi do WSA (art. 30c).

D.R. Kijowski, Umowy w administracji publicznej, [w:] Podmioty administracji publicznej i prawne formy ich działania: studia i materiały z Konferencji Naukowej poświęconej Jubileuszowi 80-tych urodzin Profesora Eugeniusza Ochendowskiego, Toruń 2005, s. 284. Niektórzy autorzy opowiadają się również za zwiększaniem cywilistycznej samodzielności kontraktowej j.s.t., zob. np. P. Stec, Umowy w administracji. Studium cywilnoprawne, Warszawa 2013; W. Gonet, Zakres swobody.... s. 58-62. 
reżimu prawnego w zakresie środków ochrony prawnej stron stosunku dotacyjnego. W sytuacji, gdy organ dotujący, np. organ wykonawczy j.s.t., wyda na podstawie przepisów u.f.p. decyzję o zwrocie dotacji, nie ma wątpliwości (w świetle ww. art. 60-61 u.f.p.), iż właściwym trybem odwoławczym jest tryb administracyjnoprawny - czyli odwołanie do SKO, a następnie droga sądowoadministracyjna - skarga na decyzję SKO do WSA. Powyższy tryb administracyjny dochodzenia zwrotów dotacji ma zastosowanie także w przypadku zawierania umowy dotacyjnej, która zgodnie z art. 250 u.f.p. jest obligatoryjna przy udzielaniu dotacji celowych. Jeśli jednak zastrzeżenia co do wysokości przekazanej dotacji zgłasza druga strona stosunku dotacyjnego - czyli jej beneficjent - przepisy prawa nie wskazują dla niej środków ochrony prawnej i rodzaju drogi sądowej, zaś próba skarżenia przez beneficjenta dotacji czynności dotacyjnych dokonywanych przez organ dotujący do sądu administracyjnego kończy się zazwyczaj wydaniem postanowienia oddalającego skargę $\mathrm{z}$ tego powodu, że nie ma ona usprawiedliwionych podstaw ${ }^{23}$ lub odrzucającego ją z tego powodu, że sprawa nie należy do właściwości sądu administracyjnego ${ }^{24}$.

\section{Podsumowanie}

W celu usystematyzowania i standaryzacji stosunków umownych (kontraktowych) nawiązywanych przez polskie organy administracji publicznej należałoby oczekiwać, aby ustawodawca powrócił jednak do koncepcji uregulowania umowy administracyjnej w k.p.a., czerpiąc ze wzorców obowiązujących w tym zakresie w ustawodawstwie zarówno niemieckim, jak i francuskim. Należy przy tym wskazać na konieczność określenia charakteru prawnego umów dotacyjnych (i im podobnych) zawieranych

Zob. postanowienie WSA w Warszawie z dnia 19 lipca 2012 r., V SA/Wa 1424/12.

Zob. postanowienie WSA w Warszawie z dnia 12 stycznia 2012 r., V SA/Wa 2235/11 i w tej samej sprawie postanowienie NSA z dnia 11 kwietnia 2012 r., II GSK 562/12. O właściwości sądowej w sprawach dotacyjnych zob. szerzej: A. Ostrowska, Samorzqdowe prawo dotacyjne. Dotacje jako wydatki jednostek samorzqdu terytorialnego, Warszawa 2018, s. 176-182. 
w Polsce, w szczególności na wzór umów administracyjnych we Francji. Tymczasem umowę dotacyjną stosowana w Polsce należy uznać jako cywilistyczny instrument wykonania czynności administracyjnej udzielenia dotacji, gdyż z całą pewnością umowa ta posiada charakter specjalnej umowy administracyjnej. Na specjalny i administracyjny charakter umowy dotacyjnej wskazuje również fakt jednostronnego ustalania jej treści przez organ dotujący z uwzględnieniem elementów wymienionych w art. 250 u.f.p. lub w ramowym wzorze umowy. Polski ustawodawca powinien jednoznacznie określić wyżej wskazany charakter umowy dotacyjnej, czyniąc to $\mathrm{w}$ formie regulacji generalnej (zasady ogólnej umieszczonej w u.f.p.), do której powinny odsyłać ustawy odrębne przewidujące państwowe i samorządowe dotowanie.

\section{Bibliografia:}

Cieślik Z., Umowa administracyjna w państwie prawa, Zakamycze, Kraków 2004.

Doliwa A., Osobowość prawna jednostek samorzq̨du terytorialnego, C.H. Beck, Warszawa 2012.

Gonet W., Zakres swobody zawierania umów przez jednostki samorzq̨u terytorialnego, Lex a Wolters Kluwer business, Warszawa 2011.

Kijowski D.R., Umowy w administracji publicznej, [w:] Podmioty administracji publicznej i prawne formy ich działania: studia i materiały z Konferencji Naukowej poświęconej Jubileuszowi 80-tych urodzin Profesora Eugeniusza Ochendowskiego, TNOiK, Toruń 2005.

Kijowski D.R., W sprawie charakteru prawnego umów zawieranych przez organy administracji, „Państwo i Prawo” 1987, nr 6, s. 77-87.

Maciołek M., Kryteria kwalifikacyjne kontraktu administracyjnego we francuskiej nauce prawa administracyjnego, „Studia Iuridica” 1996, t. 32, s. 173-178.

Ostrowska A., Dotowanie sportu przez jednostki samorzq̨u terytorialnego, „Finanse Komunalne” 2013, nr 12, s. 5-20.

Ostrowska A., Samorzqdowe prawo dotacyjne. Dotacje jako wydatki jednostek samorzq̨du terytorialnego, Wolters Kluwer, Warszawa 2018.

Stec P., Umowy w administracji. Studium cywilnoprawne, Difin, Warszawa 2013. 
Stefańska E., Umowy zawierane w sferze administracji publicznej - wybrane zagadnienia, [w:] J. Boć, L. Dziewięcka-Bokun (red.), Umowy w administracji, Wrocław 2008.

Śledzińska A., Umowy administracyjne w prawie i praktyce innych krajów, [w:] J. Boć, L. Dziewięcka-Bokun (red.), Umowy w administracji, Kolonia Limited, Wrocław 2008.

Zimmermann J., Prawo administracyjne, Wolters Kluwer, Warszawa 2016. 